\title{
ANALISIS KESEPAKATAN PENINGKATAN PRODUKTIVITAS KOPI ARABIKA PADA PENGEMBANGAN KAWASAN DI KABUPATEN TORAJA UTARA
}

Analysis Of Agreement Of Increasing Productivity Of Arabican Coffee In Area Development In Toraja Utara Regence

\author{
Sunanto, Salim, dan Abdul Wahid Rauf \\ Balai Pengkajian Teknologi Pertanian (BPTP) Sulawesi Selatan \\ Kontak Penulis : sunanto_bptpsulsel@yahoo.co.id
}

\begin{abstract}
Abstrak
Peningkatan produktivitas kopi merupakan upaya untuk memberikan penambahan mutu atau kualitas produk, melalui penerapan teknologi sesuai pedoman pengelolaan tanaman dengan baik dan benar. Pencapaian produktivitas kopi di Indonesia masih rendah yaitu baru mencapai $700 \mathrm{~kg} / \mathrm{ha} /$ tahun. sedangkan potensi yang dimilikinya yaitu $1.200 \mathrm{~kg} / \mathrm{ha} / \mathrm{thn}$. Petani sebagai pelaku utama usahatani kopi Arabika memiliki peranan yang sangat kuat dalam mengambil keputusan pelaksanaan kegiatan usahatani kopi Arabika. Penelitian ini dilaksanakan pada bulan Januari hingga Desember 2018. Pelaksanaannya di Kecamatan Kapalapitu Kabupaten Toraja Utara. Penentuan lokasi ini berdasarkan bahwa lokasi kegiatan sebagai lokasi pengembangan tanaman kopi Arabika. Jumlah petani yang diambil sebagai sampel sebanyak 60 petani yaitu Kelompok Tani Harapan (30 petani) dan Kelompok Tani Marannu (30 petani). Metode analisis data yang digunakan untuk mengetahui biaya pada tahun berjalan. Sedangkan analisis respon petani terhadap peningkatan produksi kopi Arabika, menggunakan analisis uji kesepakatan konkordansi kendall's. Hasil penelitiaan menujukkan Karakteristik petani kopi Arabika di wilayah Kabupaten Toraja Utara memiliki kelompok usia produktif. Tingkat pendidikan yang dimiliki sebagian besar pada pendidikan 7-9 tahun. Anggota rumah tangga tani sebagian besar berkisar 3-5 anggota/kk. Penerapan kegiatan usahatani kopi Arabika yang dilakukan oleh petani belum optimal. Seperti penggunaan bahan tanam petani masih menggunakan bibit yang tumbuh disekitar tanaman kopi dari biji yang dipetik jatuh. Petani menilai terhadap kesubutan tanaman kopi Arabika pada kelompok sedang. Sedangkan tingkat produktivitas tanaman kopi dikelompokkan sedang. Petani mengenal terhadap pupuk organik sudah bagus. Upaya peningkatan produktivitas kopi Arabika petani sepakat melalui: penyuluhan/pelatihan yang intensif dan penyebaran informasi teknologi produksi kopi Arabika. Usahatani kopi dengan penerapan teknologi dapat meningkatkan produksi dan pendapatan petani dengan MBCR 2,01.
\end{abstract}

Kata Kunci : Kopi Arabika, produktivitas, kesepakatan.

\section{abstract}

Increased coffee productivity is an effort to provide additional quality or product quality, through the application of technology in accordance with the guidelines for managing plants properly and correctly. The achievement of coffee productivity in Indonesia is still low, reaching only $700 \mathrm{~kg} / \mathrm{ha} /$ year. While its potential is $1,200 \mathrm{~kg} / \mathrm{ha} /$ year. Farmers as the main actors of Arabica coffee farming 
have a very strong role in making decisions regarding the implementation of Arabica coffee farming activities. This research was conducted from January to December 2018. The implementation was in Kapalapitu District, North Toraja Regency. Determination of this location is based on the location of the activity as a location for developing Arabica coffee plants. The number of farmers taken as a sample is 60 farmers, namely the Harapan Farmers Group (30 farmers) and the Marannu Farmers Group (30 farmers). Data analysis method used to determine costs in the current year. While the analysis of farmers' responses to the increase in Arabica coffee production, using a test analysis of Kendall's agreement. The results of the research show the characteristics of Arabica coffee farmers in the North Toraja Regency region that have a productive age group. The level of education held is mostly for education 7-9 years. Most members of farm households range from 3-5 members/family. The application of Arabica coffee farming activities carried out by farmers is not optimal. Like the use of planting material, farmers still use seeds that grow around the coffee plant from the seeds that are picked down. Farmers assess the fertility of Arabica coffee plants in the medium group. While the productivity level of coffee plants is classified as medium. Farmers know about organic fertilizer is good. Efforts to increase the productivity of Arabica coffee farmers agree through: intensive counseling/training and information dissemination on Arabica coffee production technology. Coffee farming with the application of technology can increase the production and income of farmers with MBCR 2.01.

Keywords: Arabica coffee, productivity, agreement.

Sunanto, Salim, dan Abdul Wahid Rauf, 2019.. Analisis Kesepakatan Peningkatan

Produktivitas Kopi Arabika Pada Pengembangan Kawasan Di Kabupaten Toraja Utara, JSEP 15(1): 42 - 55

\section{Pendahuluan}

Peningkatan produktivitas kopi merupakan upaya untuk memberikan penambahan mutu atau kualitas produk, melalui penerapan teknologi sesuai pedoman pengelolaan tanaman dengan baik dan benar. Upaya ini untuk memenuhi kebutuhan masyarakat pencinta kopi. Suara Pembaharuan (2018), melaporkan bahwa organisasi dunia memprediksi pada tahun 2010 akan terjadi defisit kopi 10 juta karung. Kondisi tersebut menjadi peluang besar bagi Indonesia untuk memenuhi kebutuhan tersebut. Sebab didukung oleh potensi agroekosistem yang sesuai. Namun demikian perlu dukungan kerjasama antara petani, pemerintah, dan eksportir dalam rangka meningkatkan produktivitasnya.

Pencapaian produktivitas kopi di Indonesia baru mencapai $700 \mathrm{~kg} / \mathrm{ha} / \mathrm{tahun}$. Kondisi ini masih mampu ditingkatkan menjadi potensi yang dimilikinya yaitu 1.200 $\mathrm{kg} / \mathrm{ha} / \mathrm{thn}$. Upaya yang dapat ditempuh melalui peran pemerintah memberikan kepastian ketersediaan bibit bermutu dan pupuk di lapang (Kementan, 2019).

Aspek budidaya dalam kegiatan usahatani kopi menjadi faktor utama dalam peningkatan produktivitas. Puslitbangbun (2015), melaporkan bahwa rendahnya produktivitas kopi arabika di Indonesia sampai saat ini belum digunakannya bahan tanam unggul tahan terhadap penyakit karat daun, atau tahan serangan nematoda parasit. Enam varietas unggul tanaman kopi arabika antara lain: Andongsari 1, Kartika 1, Kartika 2, Abesinia, Line S 795, dan USDA 762. Potensi produktivitas 
tanaman kopi arabika antara 0,7 - 2,5 ton/ha, dengan populasi tanaman 2.500 phn/ha (Puslitbangbun, 2015a).

Penerapan teknologi usahatani kopi Arabika yang dapat mendukung peningkatan produktivitasnya antara lain melalui; kinerja kelembagaan petani, penggunaan bahan tanam, pemupukan, pengendalian hama penyakit, dan pemanenan. Kinerja kelembagaan petani perlu ditingkatkan peranannya. Herminingsih (2011), menyatakan bahwa penguatan peran kerjasama dalam kelembagaan kelompok tani agar kelompok tani mampu bertahan terhadap intervensi dari lembaga eksternal. Selain itu juga perlu memperkuat peran unit produksi dan ekonomi untuk memberikan keuntungan dan kesejahteraan bagi anggotanya. Hal tersebut untuk menjaga stabilitas kelompok tani tetap kompak.

Bibit tanaman kopi Arabika yang bermutu memberikan peranan yang sangat besar terhadap produksi. Bahan tanam yang memiliki kualitas yang baik dapat mengurangi serangan terhadap hama penyakit yang berdampak pada perbaikan mutu produksi biji kopi (Arwana et al., 2010). Anonim (2018), melaporkan penggunaan pupuk organik mampu memberikan peningkatan kualitas hasil biji kopi arabika. Pemeliharaan tanaman kopi melalui pemupukan juga menjadi faktor dalam peningkatan produktivitasnya. Pemberian tambahan unsur hara pada tanah untuk tanaman sangat diperlukan, baik yang berasal dari bahan organik maupun anorganik. Hulupi dan Martini (2013) merekomendasikan bahwa pemupukan pada tanaman kopi diberikan pada awal dan akhir musim hujan, pemberiannya sesuai umur tanaman dan dosisnya.

Pengelolaan tanaman kopi yang baik melalui pemeliharaan, maka pada saat pengambilan hasil, perlakuan panen harus tepat. Tepat waktu umur panen, tingkat kemasakan, dan penanganan setelah dipanen. Hal ini dilakukan untuk mempertahankan kualitas biji kopi. Wardani (2015) melaporkan bahwa klasifikasi pemasakan buah kopi terbagi menjadi 4 klas yaitu, buah hijau, buah kuning kemerahan, buah merah, dan buah merah kehitaman. Hasil pemanenan kopi yang dicapai adalah buah kopi inferior mencapai 2,72 \% masih dibawah standar buah kopi inferior. Sedang buah kopi superior yang dicapai 97,28 \% dengan standar $90 \%$. Dengan demikian capaian buah kopi sudah melampaui standar buah kopi superior.

Petani sebagai pelaku utama usahatani kopi Arabika memiliki peranan yang sangat kuat dalam mengambil keputusan pelaksanaan kegiatan usahatani kopi Arabika. Kemampuan manajemen dan teknis yang dimiliki petani cukup terbatas. Petani kopi rakyat masih memiliki permasalahan dalam mengembangkan usahataninya, misalnya dalam hal masalah teknis dan manajemen yang dihadapi petani untuk memenuhi standar perusahaan dan pasar internasional (Saragih, 2010). Masalah yang dihadapi petani tersebut secara langsung mempengaruhi produktivitas kopi.

Perilaku petani dalam pengambilan keputusan berusahatani dapat dipengaruhi oleh beberapa pertimbangan. Pertimbangan ekonomi seperti profitabilitas, efisiensi, dan produktivitas lebih dari pada itu, menjaga lingkungan dan kehidupan sosial yang lebih baik merupakan hal yang penting bagi pertanian berkelanjutan dan ketiganya harus ada keseimbangan dan merupakan sebuah sistem dalam pertanian berkelanjutan. Perilaku petani dalam mengelola resiko lingkungan dipengaruhi oleh penguasaan luas lahan, pendapatan usahatani kopi, dan keikitsertaan petani pada program sertifikasi (Astuti, 2010). 


\section{Metodologi}

Penelitian ini dilaksanakan pada bulan Januari hingga Desember 2018. Pelaksanaannya di Kecamatan Kapalapitu Kabupaten Toraja Utara. Penentuan lokasi ini berdasarkan bahwa lokasi kegiatan sebagai lokasi pengembangan tanaman kopi Arabika. Sehingga untuk memperbaiki produktivitasnya, maka juga dilakukan penelitian kesepakatan peningkatan produktivitas kopi.

Penelitian menggunakan metode survei dan displai pendampingan pengembangan kawasan perkebunan kopi. Metode pengambilan sampel pada survei dilakukan dengan menggunakan teknik Purposive Sampling, yaitu teknik sampling yang didasarkan pada pertimbangan dan kriteria tertentu berdasarkan tujuan penelitian, yaitu petani kopi Arabika dataran tinggi. Jumlah petani yang diambil sebagai sampel sebanyak 60 petani yaitu Kelompok Tani Harapan (30 petani) dan Kelompok Tani Marannu (30 petani).

Untuk mengetahui respon petani terhadap upaya peningkatan produktivitas kopi Arabika, maka dilakukan verifikasi teknologi usahatani kopi melalui pendampingan pengembangan kawasan perkebunan kopi. Luas pendampingan pengembangan kawasan kopi 75 ha.

Teknik yang dipergunakan untuk mengumpulkan data adalah metode wawancara dengan menggunakan alat bantu kuesioner yang disesuaikan dengan kebutuhan data dan informasi yang diperlukan. Data yang diperlukan adalah data primer tentang karakteristik petani, biaya serta penerimaan usahatani, respon petani terhadap penerapan teknologi usahatani kopi Arabika dataran tinggi yang diperoleh secara langsung dari petani.

Metode analisis data yang digunakan untuk mengetahui biaya pada tahun berjalan:

1. Usahatani adalah $\mathrm{TC}=\mathrm{FC}+\mathrm{VC}$

Keterangan :

$\mathrm{TC}=$ Total biaya $(\mathrm{Rp})$,

$\mathrm{FC}=$ Jumlah biaya tetap (penyusutan, pajak tanah) (Rp) dan

$\mathrm{VC}=$ Jumlah biaya variabel (tenaga kerja keluarga, tenaga kerja luar, benih, pupuk, pestisida) (Rp).

2. Untuk mengetahui Penerimaan usahatani menggunakan rumus $\mathrm{TR}=\mathrm{Y}$. Py

Keterangan :

$\mathrm{TR}=$ Total penerimaan,

$\mathrm{Y}=$ Produksi yang diperoleh $(\mathrm{Kg})$ dan

Py $=$ Harga $Y(R p)$

3. Untuk mengetahui Pendapatan usahatani menggunakan rumus

$\mathrm{Pd}=\mathrm{TR}-\mathrm{TC}$

Keterangan :

$\mathrm{Pd}=$ Pendapatan usahatani $(\mathrm{Rp})$,

$\mathrm{TR}=$ Total penerimaan $(\mathrm{Rp})$ dan

$\mathrm{TC}=$ Total biaya mengusahakan (Rp) (Soekartawi, $2006: 58)$.

4. Untuk mengkaji efisiensi usahatani menggunakan rumus :

$\mathrm{R} / \mathrm{C}=\mathrm{TR} / \mathrm{TC}$

Keterangan :

$\mathrm{R} / \mathrm{C}=$ Revenue cost ratio,

$\mathrm{TR}=$ Total revenue dan 
$\mathrm{TC}=$ Total cost

Kriteria :

Jika $\mathrm{R} / \mathrm{C}>1$, maka usahatani efisien,

jika $\mathrm{R} / \mathrm{C}=1$, maka usahatani dalam keadaan impas (tidak rugi dan tidak

untung) dan jika $\mathrm{R} / \mathrm{C}<1$, maka usahatani tidak efisien

5. Analisis respon petani terhadap peningkatan produksi kopi Arabika.

Menggunakan analisis uji kesepakatan konkordansi kendall's dengan rumus (Siegel, 1997) sebagai berikut :

$$
W=\frac{S}{1 / 12 . K\left(N^{2}-N\right)}
$$

dimana :

$\mathrm{W}=$ Tingkat kecocokan (kesepakatan)

$\mathrm{s}=$ Jumlah kuadrat deviasi observasi dari mean $\left.\mathrm{R}_{\mathrm{i}}, \mathrm{s}=\sum \underset{\sum \mathrm{Ri}}{\mathrm{Ri}-} \quad\right)^{2}$

$\mathrm{k}=$ Banyak himpunan rangking perjenjangan (banyak penilai)

$\mathrm{N}=$ Banyaknya obyek atau individu yang diberi nilai

Untuk menguji signifikansi $\mathrm{W}$ pada sampel-sampel besar menggunakan rumus distribusi chi-square dengan $\mathrm{db}=\mathrm{N}-1$, yaitu :

$\mathrm{X}^{2}=\mathrm{k}(\mathrm{N}-1) \mathrm{W}$

Kriteria pengambilan keputusan dengan menggunakan nilai $\mathrm{X}^{2}$ pada tingkat kepercayaan 95\%:

1. Jika $X^{2}$ hit $\geq X^{2}$ tab, maka Ho ditolak, berarti ada kecocokan (kesepakatan) yang nyata dalam meranking kegiatan demplot pupuk organik diantara petani.

2. Jika $X^{2}$ hit $<X^{2}$ tab maka Ho diterima, berarti tidak ada kecocokan (kesepakatan) yang nyata dalam meranking kegiatan demplot pupuk organik diantara petani.

\section{Hasil dan Pembahasan}

\section{Karakteristik Petani Kopi}

Pelaksanaan kegiatan ini dilakukan pada 2 Kelompok Tani yaitu Kelompok Tani Harapan dan Kelompok Tani Marannu Lembang Benteng Mamulu Kecamatan Kapalapitu Kabupaten Toraja Utara. Petani sebagai pelaksana usahatani kopi Arabika dataran tinggi memiliki karakteristik. Karakteristik ini mempengaruhi cara dan pola usahatani kopi Arabika. Identitas petani yang dikumpulkan meliputi umur petani, pendidikan, anggota keluarga, pengalaman, dan penguasaan lahan. Adapun identitas petani secara keseluruhan disajikan pada Tabel 1, 2, 3, 4, dan 5 .

Kelompok umur petani kopi Arabika yang berada di lokasi pengembangan kawasan kopi, sebagian besar pada kelompok umur 36 - 45 tahun mencapai 18 petani atau 30,00\%. Kemudian diikuti pada kelompok umur 26 - 35 dan 46 - 55 tahun yaitu mencapai 15 petani atau 25,00\%. Urutan terakhir adalah kelompok umur $>56$ tahun yaitu mencapai 12 petani atau $20,00 \%$. 
Tabel 1

Karaktersitik umur petani kopi Arabika dataran tinggi, 2018.

\begin{tabular}{lccc}
\hline No & Kelompok Umur (thn) & Jumlah (petani) & $\%$ \\
\hline 1 & $26-35$ & 15 & 25,00 \\
2 & $36-45$ & 18 & 30,00 \\
3 & $46-55$ & 15 & 25,00 \\
4 & $\unrhd 56$ & 12 & 20,00 \\
\hline & Jumlah & 60 & 100,00
\end{tabular}

Sumber : Analisis data primer, 2018.

Berdasarkan Tabel 1 tersebut, menunjukkan kelompok usia petani kopi pada kedua kelompok tani lokasi pengembangan kawasan kopi termasuk dalam kategori usia produktif. Larsito (2005), melaporkan bahwa umur produktif yang bekerja di negara-negara berkembang pada umumnya adalah 15-55 tahun, artinya kemampuan untuk bekerja lebih baik dari usia lanjut dan anak-anak serta dalam berusahatani kemungkinan untuk meningkatkan hasil masih dapat ditingkatkan bila disertai kemampuan usaha. Hal tersebut sependapat dengan hasil penelitian Mardani et al (2017) bahwa petani jagung di Kabupaten Bireuen juga kelompok umur produktif mendominasi pada karakteristik petani.

Tabel 2

Karaktersitik tingkat pendidikan petani kopi Arabika dataran tinggi, 2018.

\begin{tabular}{lccc}
\hline No & Tingkat Pendidikan (th) & Jumlah (Petani) & $\%$ \\
\hline 1 & $\leq 6$ & 15 & 25,00 \\
2 & $7-9$ & 28 & 46,67 \\
3 & $10-12$ & 13 & 21,67 \\
4 & $\geq 13$ & 4 & 6,66 \\
\hline & Jumlah & 60 & 100,00 \\
\hline
\end{tabular}

Sumber : Analisis data primer, 2018.

Tingkat pendidikan mempengaruhi upaya dalam peningkatan pengetahuan dan ketrampilan petani. Sebagian besar petani masih memiliki tingkat pendidikan yang rendah yaitu setara lulus sekolah dasar. Sedangkan petani yang memiliki pendidikan lebih dari sepuluh tahun mencapai 13 petani atau 21,67 \%. Selanjutnya yang lulus setara sekolah menengah pertama adalah 4 petani atau 6,66 \%. Hal ini sependapat dengan Budiartiningsing et al (2010), bahwa pendidikan pada kegiatan usahatani sebagaian besar berpendidikan dasar. Hal tersebut juga diungkapkan oleh Susanti et al (2016), bahwa tingkat pendidikan berpengaruh positif terhadap peningkatan produksi usahatani.

\section{Tabel 3}

Karaktersitik jumlah anggota keluarga petani kopi Arabika dataran tinggi, 2018.

\begin{tabular}{lccc}
\hline No & Jumlah Anggota Keluarga (jiwa) & Jumlah (petani) & $\%$ \\
\hline 1 & $\leq 2$ & 6 & 10,00 \\
2 & $3-5$ & 51 & 85,00 \\
3 & $\geq 6$ & 3 & 5,00 \\
\hline & Jumlah & 60 & 100,00
\end{tabular}

Sumber : Analisis data primer, 2018. 
Jumlah anggota rumah tangga petani, setiap keluarga berbeda-beda jumlahnya. hal ini akan berpengaruh terhadap tingkat pendapatan dan alokasi pendapatannya. Karena semakin banyak jumlah anggota keluarga akan mendorong keluarga untuk mencari sumber pendapatan yang lebih banyak. Hal ini sependapat dengan Budiartiningsih et al (2010), bahwa semakin banyak anggota keluarga mendorong keluarga untuk mencari penambahan pendapatan rumah tangga secara informal untuk memenuhi kebutuhan yang semakin banyak pula.

Anggota keluarga yang melebihi dari enam anggota adalah mencapai 3 petani atau $5 \%$. Banyaknya anggota keluarga ini, karena anggota keluarga itu ada tambahan yaitu orang tua, atau keluarga dalam satu keluarga terdiri lebih dari satu kepala keluarga.

Tabel 4

Karaktersitik pengalaman petani kopi Arabika dataran tinggi, 2018.

\begin{tabular}{lccc}
\hline No & Pengalaman Berusahatani (thn) & Jumlah (petani) & $\%$ \\
\hline 1 & $\leq 5$ & 8 & 13,33 \\
2 & $6-15$ & 19 & 31,67 \\
3 & $16-25$ & 15 & 25,00 \\
4 & $26-35$ & 14 & 23,33 \\
5 & $\geq 36$ & 4 & 6,67 \\
\hline & Jumlah & 60 & 100,00 \\
\hline
\end{tabular}

Sumber : Analisis data primer, 2018.

Pengalaman menjadi peranan yang mempengaruhi pengetahuan dan ketrampilan dalam kegiatan usahatani kopi Arabika dataran tinggi. Karena teknologi usahatani pertanian selalu mengalami perubahan seiring waktu berjalan. Namun petani tidak selalu dapat mencapai tingkat efisiensi dan produktivitas yang diharapkan. Walaupun mempergunakan paket teknologi yang sama dan di lahan yang sama sekalipun, keragaman selalu muncul. Hal ini disebabkan oleh faktor, baik yang dapat dikendalikan (internal) maupun yang tidak dapat dikendalikan atau eksternal (Coelli dan Battese, 1998).

Tabel 5.

Karaktersitik penguasaan lahan petani kopi Arabika dataran tinggi, 2018.

\begin{tabular}{lccc}
\hline No & Penguasaan Lahan (ha) & Jumlah (petani) & $\%$ \\
\hline 1 & $\leq 0,25$ & 9 & 15,00 \\
2 & $0,26-0,5$ & 6 & 10,00 \\
3 & $0,51-0,75$ & 23 & 38,33 \\
4 & $0,76-1$ & 12 & 20,00 \\
5 & $\geq 1$ & 10 & 16,67 \\
\hline
\end{tabular}

Sumber : Analisis data primer, 2018.

Lahan juga sebagai faktor untuk menentukan produktivitas suatu produk pertanian, demikian juga untuk menentukan jumlah produksi kopi Arabika dataran tinggi. Kelompok pemilikan lahan terbanyak pada pemilikan luas lahan $0,51-0,75$ ha mencapai 23 petani atau $38,33 \%$. Selanjutnya diikuti pemilikan 0,76 - 1 ha mencapai 12 petani atau 20,00 \%. Sedangkan penguasaan lahan tersempit pada kelompok 0,25 - 0,50 ha hanya 10,00 \%. Manatar et al (2017) melaporkan 
bahwa pengaruh status penguasaan lahan terhadap pendapatan petani, pendapatan yang paling tinggi adalah pendapatan petani penyewa. Pendapatan yang berbeda adalah pendapatan petani milik sendiri dengan pendapatan petani penyewa. Demikian juga Mufti dan Zargustin (2017) melaporkan bahwa dari segi luas lahan yang dimiliki petani, petani yang tergolong miskin sebahagian besar petani memiliki luas lahan yang relatif sempit berkisar antara 0-0,25 Ha. Kondisi ini tentu akan mempengaruhi produktivitas dari usahatani yang dilakukan. Oleh sebab itu petani lahan kering pada lokasi penelitian yang masuk kategori miskin mencapai 9 petani atau $15,00 \%$.

Penguasaan lahan pertanaman kopi yang dimiliki oleh petani tidak dalam satu hamparan. Tetapi setiap petani dalam penguasaannya lokasi lahannya terpencarpencar dalam luasan yang sempit-sempit. Sehingga hal ini juga mempengaruhi efisiensi tenaga kerja dalam mengelola usahatani kopi Arabika.

\section{Keragaan Penerapan Teknologi}

Petani kopi dalam mengusahakan komoditasnya masih belum intensif. Hal itu masih perlu peningkatan, agar memperoleh mutu kopi yang maksimum. Eksistensi teknologi budidaya tanaman kopi dan pengembangan kelembagaan yang dilakukan oleh petani, adalah sebagai berikut pada Tabel 6 .

Tabel 6. Penerapan teknologi produksi kopi Arabika dataran tinggi, 2018

\begin{tabular}{|c|c|c|}
\hline No & Uraian & Keterangan \\
\hline 1 & Bahan Tanam & $\begin{array}{l}\text { Sebagian besar petani menanam bibit asal biji di } \\
\text { lapang' }\end{array}$ \\
\hline 2 & Pemupukan & $\begin{array}{l}\text { Penggunaan pupuk organik belum banyak } \\
\text { digunakan oleh petani. Petani menggunakan } \\
\text { pupuk Urea dan NPK, dan ZA belum sesuai } \\
\text { dengan rekomendasi }\end{array}$ \\
\hline 3 & Pengendalian Gulma & $\begin{array}{l}\text { Gulma yang ada di kebun petani dikendalikan } \\
\text { secara manual. }\end{array}$ \\
\hline 4 & $\begin{array}{l}\text { Pengendalian Hama } \\
\text { Penyakit }\end{array}$ & $\begin{array}{l}\text { Pengendalian hama penyakit tanaman kopi, petani } \\
\text { menggunakan insektisida maupun fungisida. Hal } \\
\text { ini dapat meningkatkan residu pada biji kopi. }\end{array}$ \\
\hline 5 & $\begin{array}{l}\text { Panen dan Pasca } \\
\text { Panen }\end{array}$ & $\begin{array}{l}\text { Panen dilakukan setiap satu-dua minggu sekali, } \\
\text { dengan memperhatikan buah yang sudah tua. }\end{array}$ \\
\hline 6 & Produksi & $\begin{array}{l}\text { Produktivitas tanaman kopi yang dimiliki petani } \\
\text { belum optimal berkisar antara } 800-1.200 \mathrm{~kg} / \mathrm{ha} \\
\text { berat kering jemur } 3 \text { hari. }\end{array}$ \\
\hline 7 & $\begin{array}{l}\text { Pemasaran hasil biji } \\
\text { kopi }\end{array}$ & $\begin{array}{l}\text { Pemasaran hasil biji kopi masih mengandalkan } \\
\text { pada pedagang pengumpul, sehingga kurang } \\
\text { memberikan posisi tawar petani. }\end{array}$ \\
\hline
\end{tabular}

Sumber : Analisis data primer, 2018.

Bahan tanam kopi sebagai bibit sebagian besar menggunakan dari biji yang tumbuh, sisa buah kopi yang dipanen dan rontoh tidak dipungut oleh petani. bibit tersebut kemudian dilakukan pemindahan tanam pada lahan yang belum ditanami kopi.

Pemeliharaan tanaman kopi dilakukan dengan menggunakan pupuk. Petani 
kopi menggunakan pupuk kimia yaitu pupuk ZA, Urea, dan NPK. petani belum banayak menggunakan pupuk organik. Hal ini disebabkan. Lahan pertanaman kopi jauh dari pemukiman. Sedangkaan pemeliharaan ternak sebagian besar ditempatkan sekitar rumah.

Gulma sebagai tanaman yang dapat mengganggu pertumbuhan dan produksi tanaman kopi. Petani mengendalikan tanaman gulma tersebut dengan menyiangi dan juga menggunakan herbisida sejenis racun rumput, baik yang sistemik maupun kontak. Demikian juga hama penyakit menjadi permasalahan dalam upaya peningkatan produksi. Upaya yang dilaakukan oleh petani dengan mengendalikan hama penyakit tanaman maupun buah kopi dengan insektisida maupun fungisida, hal ini bergantung serangannya.

Buah kopi mencapai masak fisiologis sekitar 3-4 bulan dari masa pembungaan. Tanda-tanda buah kopi masak adalah perubahan warna dari warna hijau menjadi warna merah. Apabila warna merah sudah mencapai $70 \%$, maka buah kopi siap dipanen.

Interval pemanenan pada paanen raya adalah 1-2 minggu sekali buah kopi dipanen. Pemanenan bisa mencapai 10-15 kali bergantung kondisi pertanaman kopi. Semakin selektif dalam panen, maka frekuensi panen akan lebih banyak. Hasil yang dicapai oleh petani kopi belum optimal, produksi baru mencapai $800-1.200 \mathrm{~kg} / \mathrm{biji}$ kopi kering. Produktivitas ini masih bisa ditingkatkan. Produksi kopi terbut dibeli oleh pedagang pengumpul, dimana posisi tawar petani belum kuat. Ketepatan waktu panen sangat berpengaruh terhadap mutu kopi yang dihasilkan. Oleh karena itu kopi harus di panen pada tingkat kematangan yang tepat. Tingkat kematangan dapat ditandai dengan buah yang berwarna merah terang. Salah satu penyebab rendahnya produktivitas dan mutu hasil kopi adalah penerapan teknologi yang masih terbatas. Masalah utama yang dikeluhkan petani adalah biaya produksi khususnya sarana dan tenaga kerja yang semakin mahal, sehingga petani menghemat pengeluaran dengan cara melakukan pemeliharaan sekedarnya.

Di lokasi pengembangan kopi Arabika dataran tinggi terdapat 3 jenis tanaman pelindung yang dominan yakni: Kaswarina, gamal dan lamtoro yang ditanam tidak beraturan. Kegiatan konservasi lahan dan tanaman masih jarang dilakukan petani. Belum ditemui petani yang membuat rorak sebagai tempat penampungan hasil pangkasan tanaman. Akan tetapi petani sudah memanfaatkan hijauan hasil pangkasan tanaman sebagai pupuk organik. Walaupun pupuk organik yang dimaksudkan adalah hasil dekomposisi pangkasan tanaman kopi dan tanman penaung yang membutuhkan waktu lama untuk dapat tersedia bagi tanaman. Petani kopi di lokasi pendampingan hanya melakukan pemupukan organik (pupuk kandang). Kurangnya penggunaan pupuk kimia disebabkan karena harga pupuk saat ini relatif tidak terjangkau oleh petani, sementara harga kopi masih dianggap sangat rendah. Pemangkasan yang bertujuan untuk pemeliharaan dan pemangkasan produksi sangat jarang dilakukan oleh petani. Umumnya petani setempat hanya melakukan pemangkasan ringan. Demikian pula tidak ada upaya dalam pengendalian hama penyakit tanaman secara kimia, dengan alasan mahalnya harga insektisida. Pengolahan buah dilakukan dengan cara kering/kopi dengan cangkan kering. Pengolahan buah dilakukan dengan alat processing hasil rakitan petani setempat. Seluruh petani kopi telah melakukan sanitasi dengan melakukan penyiangan dan pembersihan sekitar kebun. 


\section{Respon Petani Kopi}

Pengelolaan pupuk organik di tingkat petani Lembang Benteng Mammulu Kecamatan Kapalapitu Kabupaten Toraja Utara. Sehubungan dengan itu dilakukan pencatatan respon petani kopi Arabika. Adapun respon petani kopi terhadap pengelolaan pupuk dan pestisida organik disajikan pada Tabel 7.

Tabel 7. Respon petani terhadap pengelolaan pupuk organik, 2018.

\begin{tabular}{lll}
\hline No & \multicolumn{1}{c}{ Uraian } & \multicolumn{1}{c}{ Respon Petani } \\
\hline 1 & Kondisi pertanaman kopi & $\begin{array}{l}\text { Tidak subur }=13,95 \% \text {, sedang }=69,77 \% \\
\text { dan subur }=16,28 \% .\end{array}$ \\
2 & Tingkat produktivitas & $\begin{array}{l}\text { Rendah }=16,28 \%, \text { sedang }=60,47 \%, \\
\text { dan tinggi }=23,26 \% .\end{array}$ \\
3 & Pengenalan pupuk organik & $74,42 \%$ \\
4 & Pengenalan pestisida organik & $2,33 \%$ \\
5 & Kemauan untuk mencoba & $100 \%$ \\
\hline
\end{tabular}

Sumber: Analisis data primer, (2018).

Kondisi pertanaman kopi Arabika yang berkembang di Kabupaten Toraja Utara adalah 13,95 \% tidak subur, 69,77 \% sedang kesuburannya, dan 16,28 \% subur. Hal ini akan berpengaruh terhadap tingkat produktivitas pertanaman kopi. Tingkat produksi kopi yang masuk kategori tinggi baru mencapai 23,28 \%. Sedangkan produksi sedang mendominasinya yaitu mencapai $60,47 \%$.

Sumber pupuk organik yang berada di perdesaan sudaah sebagian besar sudah dikenali oleh petani. bahan organik yang sudah dikenal oleh petani antara lain: limbah pertanian, rerumputan, dan kotoran ternak. Namun pestisida organik belum banyak diketahui oleh petani kopi. Oleh sebab itu pengelolaan bahan organik sebagai bahan pupuk organik maupun pestisida organik, maka perlu diperkenalkan dengan jenis-jenis mikroba yang bisa dimanfaatkan sebagai pendukung pengelolaan bahan organik.

\section{Kesepakatan Peningkatan Produktivitas}

Kesepakatan yang diperoleh dari petani untuk meningkatkan produktivitas kopi Arabika dapat ditempuh beberapa hal. Upaya yang disepakati meliputi; peranan kelembagaan petani, penyuluhan/pelatihan teknologi pertanian (peran petugas pertanian), penyebaran informasi teknologi pertanian (peranan media infotan), dan peran aktif petani. hasil penilaian terhadap upaya peningkatan produktivitas kopi Arabika disajikan pada Tabel 8.

Tabel 8. Penilaian petani terhadap upaya peningkatan produktivitas kopi Arabika, 2018

\begin{tabular}{|l|l|c|c|c|}
\hline No & \multicolumn{1}{|c|}{ Hasil } & Rangking & Jumlah & $(\%)$ \\
\hline 1 & Peranan kelembagaan petani & 4 & 24 & 40,00 \\
2 & Penyuluhan/pelatihan teknologi pertanian & 1 & 34 & 56,67 \\
3 & Penyebaran informasi teknologi pertanian & 2 & 32 & 53,33 \\
4 & Peran aktif petani & 3 & 29 & 48,33 \\
\hline & W $=0,2655$ \\
\hline & X'hit $=31,8623$ \\
\hline & X'tab $=7,81$
\end{tabular}

Sumber : Analisis data primer, 2018. 
Tabel 7, menunjukkan urutan ranking preferensi petani terhadap metode yang paling disukai dalam upaya peningkatan produktivitas kopi Arabika. Urutan ranking tersebut adalah metode penyuluhan/pelatihan teknologi pertanian yang dilakukan oleh petugas, penyebaran informasi teknologi pertanian melalui media informasi pertanian, peran aktif petani, dan peranan kelembagaan petani.

Nilai kecocokan (W) yang terjadi diantara responden dalam meranking metode upaya peningkatan produktivitas adalah sebesar 0,2655 . Nilai $W$ tersebut signifikan pada tingkat kepercayaan 95 persen, yang dapat dilihat dari chi-square ( X 2 ), di mana X 2 hit lebih besar daripada X 2 tab. Hal ini berarti ada kecocokan (kesepakatan) yang nyata diantara 56,67 \% atau 34 responden dalam meranking metode upaya peningkatan produktivitas kopi.

Berdasarkan data tersebut, metode sosialisasi yang lebih disukai oleh responden adalah metode kelompok. Metode kelompok adalah metode yang mengarahkan sasaran kegiatannya pada petani secara berkelompok (kelompok tani). Kegiatan ini melibatkan kegiatan tatap muka secara langsung antara penyuluh lapang dengan kelompok tani. Metode sosialisasi ini dipilih oleh responden karena melalui metode ini

para petani yang tergabung dalam kelompok tani dapat dikoordinir dengan lebih mudah sehingga apa yang akan disampaikan dalam sosialisasi dapat diketahui oleh semua petani dengan porsi yang sama dan pada waktu sama. Metode yang dipilih oleh responden ini sudah sesuai dengan metode sosialisasi yang digunakan dalam kegiatan

demplot pupuk organik di Desa Buran Kecamatan Tasikmadu Kabupaten Karanganyar.

\section{Analisis Usahatani Kopi}

Tujuan dalam kegiatan usahatani adalah untuk memperoleh produksi yang maksimal dan pendapatan yang optimal. Demikain juga dalam kegiatan usahatani kakao untuk memperoleh produksi dan pendapatan sebagai biaya usahatani dan hidup rumah tangga tani. Adapun analisis usahatani kakao disajikan pada Tabel 12.

Hasil analisis usahatani tanaman kopi pada lokasi pendampingan di Kabupaten Toraja Utara dengan introduksi teknologi nilai penerimaan Rp. 44.250.000 dan teknologi petani mencapai Rp. 40.007.000 per tahun. Dengan demikian dampak dari pendampingan dengan introduksi tersebut dapat memberikan kenaikan penerimaan petani kopi. Hasil penerimaan dari kegiatan usahatani tanaman kopi ini untuk memenuhi kebutuhan biaya usahatani kopi berikutnya dan juga untuk memenuhi kebutuhan hidup rumah tangga tani.

Biaya sarana dan prasarana produksi usahatani kopi pada lokasi pendampingan dengan penerapan teknologi introduksi mencapai Rp. 15.075.000,dan biaya pada teknologi petani lebih sedikit dibandingkan dengan biaya usahatani menggunakan teknologi introduksi yaitu mencapai Rp. 13.725.000,- adapun biaya tenaga kerja untuk kegiatan usahatani kopi masing-masing Rp. 1.300 .000 dan Rp. 1.250.000 per tahun. Dengan demikian total biaya usahatani kopi dengan teknologi introduksi dan teknologi petani masing-masing mencapai Rp. 16.450 .000 dan Rp. 15.050.000 per tahun. 
Tabel 12. Analisis usahatani kopi pada introduksi dan teknologi petani, 2018.

\begin{tabular}{|c|c|c|c|c|c|c|c|}
\hline \multirow[b]{2}{*}{ No } & \multirow[b]{2}{*}{ Masukan/Pengeluaran } & \multicolumn{3}{|c|}{ Teknologi Introduksi } & \multicolumn{3}{|c|}{ Teknologi Petani } \\
\hline & & Jumlah & $\begin{array}{l}\text { Harga/ } \\
\text { Satuan }\end{array}$ & Nilai (Rp) & Jumlah & $\begin{array}{l}\text { Harga/ } \\
\text { Satuan }\end{array}$ & Nilai (Rp) \\
\hline \multirow[t]{4}{*}{ I } & Penerimaan 1) & & & & & & \\
\hline & 1. Produksi Fisik (kg) & $1.500 \mathrm{~kg}$ & 26.000 & 39.000 .000 & 1.357 & 26.000 & 35.282 .000 \\
\hline & 2. Sampingan & $1.500 \mathrm{~kg}$ & 3.500 & 5.250 .000 & 1.350 & 3.500 & 4.725 .000 \\
\hline & Total Penerimaan I & & & 44.250 .000 & & & 40.007 .000 \\
\hline \multirow[t]{9}{*}{ II } & Pengeluaran 2) & & & & & & \\
\hline & 1. Bibit & $1.500 \mathrm{ph}$ & 3.500 & 5.250 .000 & $1.500 \mathrm{ph}$ & 3.500 & 5.250 .000 \\
\hline & 2. Pupuk Urea & $150 \mathrm{~kg}$ & 2.150 & 3.225 .000 & $150 \mathrm{~kg}$ & 2.150 & 3.225 .000 \\
\hline & 3. Pupuk Ponskha & $200 \mathrm{~kg}$ & 2.350 & 4.700 .000 & $200 \mathrm{~kg}$ & 2.350 & 4.700 .000 \\
\hline & 4. Pupuk kandang & $1.500 \mathrm{~kg}$ & 1.000 & 1.500 .000 & - & & \\
\hline & 5. Fungisida & $1 \mathrm{lt}$ & 50.000 & 50.000 & $4 \mathrm{lt}$ & 50.000 & 200.000 \\
\hline & 6. Insektisida & & & & $5 \mathrm{lt}$ & 70.000 & 350.000 \\
\hline & 7. Biopestisida & $5 \mathrm{lt}$ & 70.000 & 350.000 & - & & \\
\hline & Total Input (II) & & & 15.075 .000 & & & 13.725 .000 \\
\hline \multirow[t]{8}{*}{ III } & Tenaga Kerja 3) & & & & & & \\
\hline & 1. Penyiangan & 3 & 50.000 & 150.000 & 3 & 50.000 & 150.000 \\
\hline & 2. Pemangkasan & 6 & 50.000 & 300.000 & 5 & 50.000 & 250.000 \\
\hline & 3. Pemupukan & 3 & 50.000 & 150.000 & 3 & 50.000 & 150.000 \\
\hline & 4. Pengendalian OPT & 6 & 50.000 & 300.000 & 6 & 50.000 & 300.000 \\
\hline & 5. Angkut panen & 5 & 50.000 & 250.000 & 5 & 50.000 & 250.000 \\
\hline & 6. Pascapanen & 3 & 50.000 & 150.000 & 3 & 50.000 & 150.000 \\
\hline & Total Tenaga Kerja III & & & 1.300 .000 & & & 1.250 .000 \\
\hline \multirow[t]{2}{*}{ IV } & Lain-lain 4) & & & 75.000 & & & 75.000 \\
\hline & Total Biaya (II+III+IV) & & & 16.450 .000 & & & 15.050 .000 \\
\hline \multirow[t]{4}{*}{$\mathbf{V}$} & Pendapatan 5) & & & 27.800 .000 & & & 24.987 .000 \\
\hline & $\mathrm{B} / \mathrm{C}$ & & & 2,70 & & & 2,66 \\
\hline & Biaya produksi $(\mathrm{Rp} / \mathrm{kg}$ & & & $10.966,67$ & & & $11.090,64$ \\
\hline & MBCR & & & 2,01 & & & \\
\hline
\end{tabular}

Sumber : Analisis data primer, (2018)

Selisih hasil antara penerimaan dan biaya tersebut menjadi pendapatan petani kopi yang dapat dijadikan sebagai pemenuhan kebutuhan rumah tangga tani kopi. Pendapatan petani dengan penerapan teknologi introduksi mencapai Rp. 27.800.000 dan yang menggunakan teknologi petani mencapai Rp. 24.987 .000 per tahun. Demikian juga ratio penerimaan dan biaya dalam tahun berjalan cukup tinggi yaitu 2,70 dan 2,66. Namun biaya produksi untuk menghasilkan $1 \mathrm{~kg}$ biji kopi kering mencapai Rp. 10.966,67 dan Rp. 11.090,64. Adapun marginal benefit cost rationya mencapai 2,01.

\section{Kesimpulan}

Karakteristik petani kopi Arabika di wilayah Kabupaten Toraja Utara memiliki kelompok usia produktif. Tingkat pendidikan yang dimiliki sebagian besar pada pendidikan 7-9 tahun. Anggota rumah tangga tani sebagian besar berkisar 3-5 anggota/kk. Penerapan kegiatan usahatani kopi Arabika yang dilakukan oleh petani belum optimal. Seperti penggunaan bahan tanam petani masih menggunakan bibit yang tumbuh disekitar tanaman kopi dari biji yang dipetik jatuh. Petani menilai terhadap kesubutan tanaman kopi Arabika pada kelompok sedang. Sedangkan tingkat produktivitas tanaman kopi dikelompokkan sedang. Petani mengenal terhadap pupuk organik sudah bagus. Upaya peningkatan produktivitas kopi 
Arabika petani sepakat melalui: penyuluhan/pelatihan yang intensif dan penyebaran informasi teknologi produksi kopi Arabika. Usahatani kopi dengan penerapan teknologi dapat meningkatkan produksi dan pendapatan petani dengan MBCR 2,01.

\section{DAFTAR PUSTAKA}

Alam, S. 2014. Kelayakan Pengembangan Kopi Sebagai Komoditas Unggulan Di Provinsi Sulawesi Selatan .http://ojs.unud.ac.id/index.php/soca/article/ viewFile/4187/3172. Diakses tanggal 11 September 2014.

Anonim. 2013. Kopi Berkelanjutan.http://ditjenbun.pertanian.go.id/pascapanen/ halkomentar-203-kopi-berkelanjutan-2.html Diakses tanggal 11 Sept 2014

2018. Penggunaan pupuk organik pada tanaman kopi arabika. Panduan Petunjuk Teknis. Leaflet. BPTP Balitbangtan. 1 hal.

Arwana I.K., N.G.A.G.E. Martiningsih, I.M. Budiasa, dan I.G. Sukarna. 2010. Peningkatan kualitas dan kuantitas kopi arabika Kintamani dalam upaya meningkatkan komoditas ekspor sektor perkebunan. Fakultas Pertanian, Universitas Mahasaraswati Denpasar. Majalah Aplikasi Ipteks Ngayah Vol. 1 No. 1, 2010. Hal 63-70.

Astuti A. P. 2010. Analisis Pendapatan Dan Perilaku Petani Dalam Menghadapi Risiko Usahatani Nanas (Ananas Comosus (L) Merr) Di Desa Astomulyo Kecamatan Punggur Kabupaten Lampung Tengah. Skripsi. Program Studi Agribisnis Fakultas Pertanian Universitas Lampung. Bandar Lampung.

Basir Napu, Jermia Limbongan, Eka Triana, Azis Bilang, dan Sunanto. 2015. Pendampingan kawasan perkebunan kopi nasional di Sulawesi Selatan. Laporan Hasil Pendampingan BPTP Sulawesi Selatan.

BPKM. 2013. http://regional investment.bkpm.go.id/newsipid/id/ commodity area. php?ic $=62 \& i a=73$ Diakses tanggal 12 September 2014

Budiartiningsih R., Y. Maulida, dan Taryono. 2010. Faktor-Faktor yang mempengaruhi peningkatan pendapatan keluarga petani di Desa Kedaburapat, Kecamatan Rangsang Barat, Kabupaten Bengkalis. Jurnal Ekonomi Vol 18 No. 1 Maret 2010. Fakultas Ekonomi Universitas Riau. Hal 79-93.

Coelli T.J. D.S.P. Rao and G.E. Battese. 1998. Introduction to efficiency and productivity analysis. Kluwer Academic Publisher. Boston.

Dinas Perkebunan Propinsi Sulawesi Selatan. 2009. Laporan Tahunan Pengembangan Kopi di Sulawesi Selatan.

Herminingsing, H. 2011. Penguatan peran lembaga kelompok tani dalam pengembangan 
usahatani kopi rakyat. Universitas Terbuka Jember. Jurnal Sosek Pertanian Vol. 5 No. 1 Maret 2011. Hal 46 - 53.

International Coffe Organization. 2010. http://www.ico.org/profilese.asp?section= Statistics Diakses tanggal 10 Sep 2014

Kementerian Pertaniaan Republik Indonesia. 2019. Rapat kopi mendukung peningkatan produksi kopi nasional. Kementan RI. Jln. Harsono RM. No. 3 Ragunan, Jakarta. 1 hal.

Larsito S. 2005. Analisis keuntungan usaha tembakau rakyat dan efisiensi ekonomi relatif menurut skala luas lahan garapan. Program Studi Magister Ekonomi dan Studi Pembangunan. Program Pascasarjana. Undip. 106 hal.

Manatar M.P., E.H. Loah, dan J.R. Mandei. 2017. Pengaruh status penguasaan lahan terhadap pendapatan petani padi di Desa Jumani Kecamatan Maesaan Kabupaten Minahasa Selatan. Jurnal Agri-SosioEkonomi Universitas Syam Ratulangi Vol 13 No 1 Januari 2017. Hal 55-64.

Mardani, T.M. Nur, dan H. Satriawan. 2017. Analisis usahatani tanaman pangan jagung di Kecamatan Juli Kabupaten Bireuen. Jurnal S. Pertanian Vol 1 No. 3 2017. Fakultas Pertanian, Universitas Almuslim. Hal 203-212.

Mufti dan D. Zargustin. Penguasaan lahan usahatani padi sawah dan hubungan dengan tingkat kemiskinan di Desa Padang Mutung Kecamatan Kampar Kabupaten Kampar. Jurnal Agribisnis Vol 19 No. 1 Juni 2017, Fakultas Pertanian Universitas Lancang Kuning. Hal 26-32.

Pusat Penelitian dan Pengembangan Perkebunan. 2015. Bahan tanaman unggul kopi. Puslitbangbun, Badan Litbang Pertanian, Kementan. 1 hal.

2015a. Varietas unggul kopi arabika. Puslitbangbun, Badan Litbang Pertanian, Kementan. 1 hal.

Saragih, J.R. 2010 Kinerja Produksi Kopi Arabika dan Prakiraan Sumbangannya dalam Pendapatan Wilayah Kabupaten Simalungun. VISI (2010) 18 (1) 98 - 112

Suara Pembaharuan. 2018. LPDB siap bantu pelaku usaha kopi di Indonesia. SP. Suara Pembaharuan, Jakarta, Rabu, 27 Februari 2018. Hal. 1

Susanti D., N.H. Lestiana, T. Widayat. 2016. Pengaruh umur, tingkat pendidikan dan luas lahan terhadap hasil produksi tanaman sembung. Jurnal Tumbuhan Obat Indonesia Vol 9 No. 2 2016. Balai Besar Penelitian dan Pengembangan Tanaman Obat dan Obat Tradisional.

Wardani Y.K. 2015. Manajemen pemanenan dan transfortasi hasil panen kopi Arabika (coffe arabica L.) di kebun Blawan, PT. Perkebunan Nusantara XII (Persero) Bondowoso, Jawa Timur. Skripsi. Departemen Agronomi dan Hortikultura, Fakultas Pertanian, IPB, Bogor. 44 hal. 